\title{
Frugivory and seed dispersal in the endemic cactus Eulychnia acida: extending the anachronism hypothesis to the Chilean Mediterranean ecosystem
}

Rocío A. Cares ${ }^{1 \dagger}$, Consuelo Sáez-Cordovez ${ }^{1 \dagger}$, Alfonso Valiente-Banuet ${ }^{2}$, Rodrigo Medel ${ }^{1 *}$ (i) and Carezza Botto-Mahan ${ }^{1}$

\begin{abstract}
Background: Eulychnia acida is an endemic Chilean cactus species whose fruits show several traits that, taken as a whole, are compatible with a seed dispersal syndrome by large herbivore vertebrates. Since only a few large native mammals exist in Chile at present, cactus fruit consumption and seed dispersal may be coopted by introduced mammals as predicted by Janzen and Martin's (1982) hypothesis for tropical ecosystems.

Findings: We describe the current frugivore species of E. acida in a protected semiarid-Mediterranean ecosystem using field measurements and feeding experiments. In addition, to examine a potential role as seed dispersers of the cactus species, we offered fruits and performed germination tests on seeds defecated by Lama guanicoe and the introduced goat Capra a. hircus under captivity conditions. Our data indicate that while fruits of E. acida are pecked by the Chilean tinamou, Nothoprocta perdicaria, and the Chilean mockingbird, Mimus thenca, and eaten by the brush-tailed rodent, Octodon degus, none of these species could be considered a legitimate seed disperser. Unlike L. guanicoe, the goat C. a. hircus did not reduce seed germination, having a neutral effect.

Conclusions: Results from this study indicate that introduced C. a. hircus was the only species showing a potential role in the seed dispersal process of E. acida. In the absence of native frugivore species, goats might play an important role in population recruitment of the endemic cactus. These results extend Janzen and Martin's (1982) anachronism hypothesis to the Chilean Mediterranean ecosystem.
\end{abstract}

Keywords: Eulychnia acida, Seed dispersal, Frugivory, Seeds, Goats, Lama guanicoe, Octodon degus, Anachronism

\section{Background}

Frugivory and seed dispersal are key ecological processes involved in the demography and maintenance of plant populations [1-4]. Frugivore species play a fundamental role in seed dispersal, as they increase the probability of seed germination by removing the pulp and/or through gut passage and carry seeds away from parental individuals to sites where the probability of seedling recruitment may be higher $[5,6]$. It has been long accepted

\footnotetext{
* Correspondence: rmedel@uchile.cl

${ }^{\dagger}$ Rocío A. Cares and Consuelo Sáez-Cordovez contributed equally to this work.

'Departamento de Ciencias Ecológicas, Facultad de Ciencias, Universidad de Chile, Las Palmeras 3425, Nuñoa, Santiago, Chile

Full list of author information is available at the end of the article
}

that current associations between plant and frugivore species are the outcome of selective forces that fit suites of fruit features to those animal species which maximize the seed dispersal process and plant recruitment $[7,8]$. Nevertheless, in some circumstances, fruits may exhibit morphological traits best explained as adaptations for seed dispersal by extinct animal species, a phenomenon referred as "seed dispersal anachronism". Guimaraes et al. [9] indicated that some current Neotropical fruits exhibit features that do not fit to dispersers present today but seem to exhibit apparent adaptations for the dispersal by large animals which are now extinct. Janzen and Martin [10] hypothesized that introduced and large herbivore vertebrates may act as surrogate dispersal

(c) The Author(s). 2018 Open Access This article is distributed under the terms of the Creative Commons Attribution 4.0 International License (http://creativecommons.org/licenses/by/4.0/), which permits unrestricted use, distribution, and 
agents in places where native frugivorous have disappeared. While in tropical forests some fleshy fruits show putative adaptations to animals that are extinct nowadays [9-11], this kind of study is lacking in Mediterranean ecosystems. This omission is unfortunate, as extinction of large herbivore mammals putatively involved in seed dispersal may be not only restricted to tropical ecosystems but encompass most Neotropical ones [10], including the current Chilean Mediterranean ecosystem.

Eulychnia acida (Cactaceae) is an endemic columnar cactus species that inhabits north-facing slopes in semiarid Chile [12] (Fig. 1). Its geographic distribution ranges from Atacama to the Coquimbo Region $\left(27^{\circ} 22^{\prime} \mathrm{S}, 70^{\circ}\right.$ $19^{\prime} \mathrm{W}$ to $29^{\circ} 57^{\prime} \mathrm{S}, 71^{\circ} 20^{\prime} \mathrm{W}$; Fig. 2) [13]. The fruit is spherical, large and indehiscent $(5-6 \mathrm{~cm}$ in diameter) (Fig. 1), with a yellowish-green color and covered with small scales [14]. Each fruit contains on average $( \pm$ SE) 1930 ( \pm 95.7$)$ small black seeds embedded in a white sour pulp ( $n=315 ; \mathrm{R}$. Medel, unpublished data). The fruiting season of $E$. acida ranges from mid-October to early-January [15]. When ripe, fruits fall from the cactus branch, which often results in a high proportion of the fruit crop lying on the ground. No native species has been hitherto reported to remove or eat them. However, in unprotected semiarid-Mediterranean areas, individuals of Capra a. hircus (goats) have been observed consuming E. acida fruits (R. Cares, personal observation), which is consistent with studies highlighting the role of goats as seed dispersers of cactus species in other latitudes. For example, Baraza and Valiente-Banuet [16] found that seeds of the endemic cactus species Echinocactus platyacanthus and Ferocactus robustus recovered from goat feces had high germination capacity. Baraza and Fernández-Osores [17] reported that goats disperse the seeds of two additional cactus species, Ferocactus flavovirens and Ferocactus latispinus. In Chile, a potential large-sized fruit consumer and disperser of $E$. acida is the native camelid Lama guanicoe (guanaco), which is sometimes observed in the foothills of the Andes Mountain Range in north-central Chile. It is likely that L. guanicoe reached high population numbers in places where nowadays it is locally extinct [18]. In the arid coast of the Atacama Desert, L. guanicoe eats mostly lichens and succulent plants, such as Eulychnia iquiquensis [19], which suggests a role in the seed dispersal process of cactus species.

The first goal of this study was to describe the native species eating the fruits and dispersing the seeds of $E$. acida. To this end, we carried out fruit-consuming field experiments in a protected area (Las Chinchillas National Reserve) and performed laboratory germination

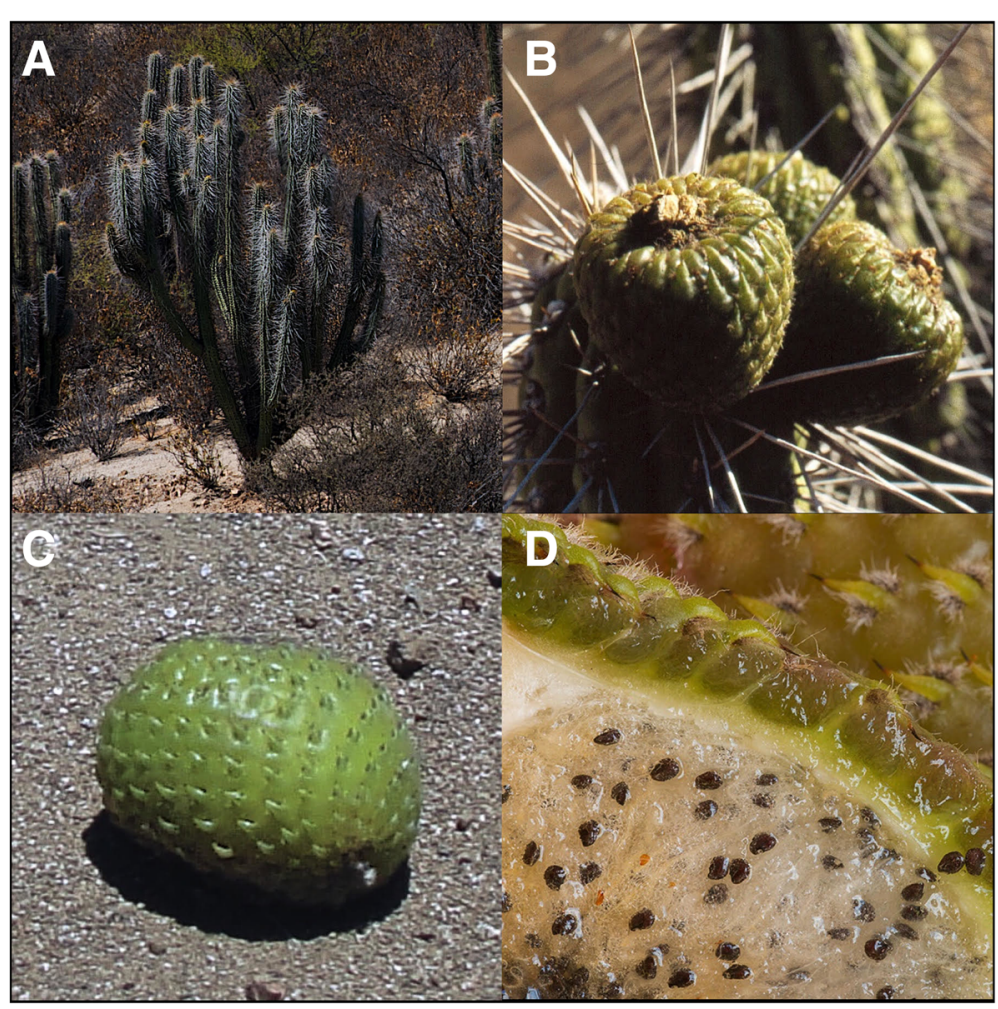

Fig. 1 Adult specimen of Eulychnia acida (a), Eulychnia acida fruit adhered to the stem of cactus (b), Eulychnia acida fruit after being naturally excised (c), and pulp of Eulychnia acida fruit (d). Pulp photograph by José Cañas 


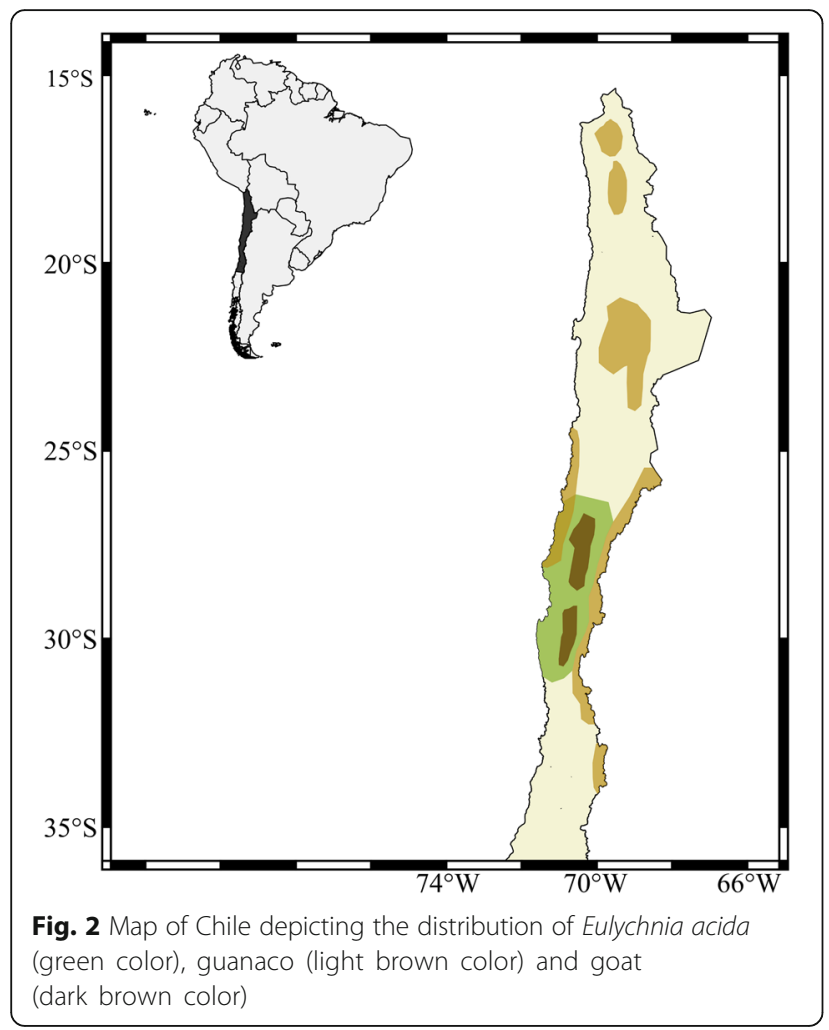

experiments. Our second goal was to evaluate whether seed passage through guanaco and goat digestive tracts enhance seed germination using no choice feeding and laboratory germination experiments. Finally, we examine the extent to which goats consume the fruits of E. acida outside the protected area, and whether this consumption could account for the different stage structure of cacti between the protected and unprotected areas. To this end, we took advantage of a natural setting provided by the National Reserve, where large introduced herbivores do not have access to cactus populations, and an unprotected area next to the Reserve where goats forage freely. More specifically, in this study we address the two following questions: (1) What native species do eat the fruits and disperse the seeds of E. acida in the Reserve? (2) Do guanacos and goats eat the fruits and increase seed germination of E. acida after gut passage? Based on our results we discuss on the functional role of guanacos and goats for the seed dispersal process of E. acida, framing our results under Janzen and Martin's anachronism hypothesis as applied to the Chilean Mediterranean ecosystem.

\section{Methods}

\section{Study site}

This study was carried out within and in the area surrounding Las Chinchillas National Reserve, a semiarid protected area of north-central Chile ( $\left.31^{\circ} 30^{\prime} \mathrm{S}, 71^{\circ} 06^{\prime} \mathrm{W}\right)$. The climate is a semiarid Mediterranean type, with most rainfall concentrated between June and August [20]. Mean annual precipitation is $185.0 \mathrm{~mm}$, with ample variation across years, alternating between long droughts and unusual years of high rainfall, seemingly associated with El Niño Southern Oscillation events. The vegetation consists of thorny shrubs such as Flourensia thurifera, Bahia ambrosioides and Porlieria chilensis [21], the columnar cactus species Trichocereus chiloensis and Eulychnia acida and the spherical cacti Cumulopuntia sphaerica and Eriosyce aurata [12, 14, 22].

\section{Frugivore recordings inside the Reserve}

To identify the species involved in E. acida fruit consumption, fifty $1 \times 1 \mathrm{~m}$ footprint-traps were established on hills of this Reserve when fresh fruits started to appear on the ground. One fresh fruit was placed as bait in the middle of each footprint-trap (mean fruit size \pm SE: $49.4 \pm 4.8 \mathrm{~mm}$ width, $48.5 \pm 3.9 \mathrm{~mm}$ length, $n=50$ ), and tied with a nylon thread to keep track of fruit and seed consumers. Traps were checked for animal tracks during six consecutive days. Footprints were recorded with a digital camera, along with a tape measure. If the fruit had not been consumed, the footprint trap was brushed again, and the fruit was left in the same place.

\section{No-choice feeding test}

Only one species was found eating fruits of E. acida inside the Reserve, the brush-tailed rodent Octodon degus. To test for fruit consumption under captivity conditions, individuals of $O$. degus (Fig. 3) were captured with folding wire mesh live animal-traps $(24 \times 8 \times 9 \mathrm{~cm})$ baited with rolled oats and provided with cotton bedding. A total of 150 traps per night were set during five consecutive days, between 19:00 and 09:00 h, and checked every morning. The captured $O$. degus $(n=33)$ were maintained inside acrylic cages in an animal room with controlled temperature $\left(25^{\circ} \mathrm{C}\right)$ and relative humidity (45-65\%). Animals were fed only with ripe fruits of $E$. acida, and after 3 days their feces were collected and visually inspected for cactus seeds. The capture of $O$. degus was performed under the permission of the Servicio Agrícola y Ganadero (resolution $\mathrm{N}^{\circ} 1792$ of April 2, 2012) and captive conditions were approved by the Ethics Committee of the Faculty of Medicine of University of Chile $(\mathrm{CBA} \neq 0443 \mathrm{FMUCH})$.

No-choice feeding experiments were also carried out with local goat individuals $(n=3)$ and guanaco specimens from the Chilean National Zoo $(n=11)$ (Fig. 3). Goats were fed with $E$. acida fruits ad-libitum and no other food source was provided. For guanacos, E. acida fruits were given ad-libitum along with alfalfa hay and 


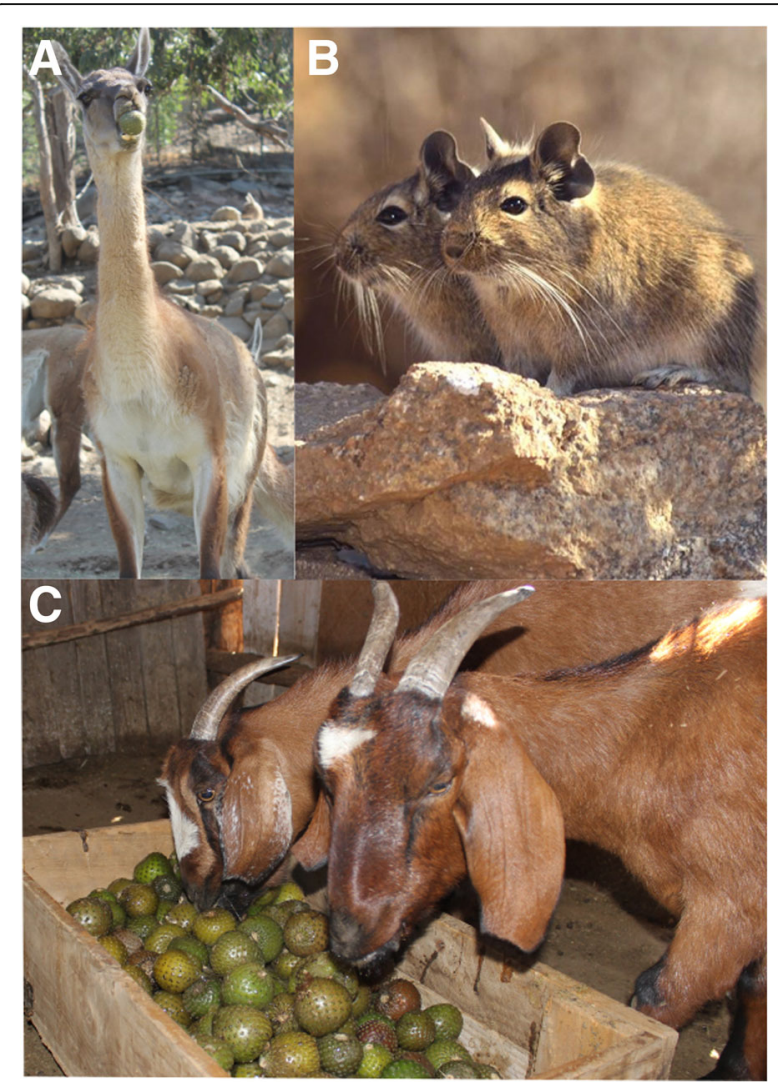

Fig. 3 Putative consumers of Eulychnia acida fruits. Lama guanicoe (a), Octodon degus (b), and Capra a. hircus (c). O. degus photograph by Jorge Abarca

Mazuri ${ }^{\ominus}$ Llama chews. Goats and guanacos were fed with E. acida fruits for 2 days and their feces collected for two consecutive days after feeding. Feces were placed in paper bags and transported to the laboratory where seeds were manually extracted. Only seeds that were intact and whole were used in germination experiments.

\section{Seed germination experiments}

Controlled experiments were performed to determine the effect of gut passage on germination of $E$. acida seeds. Seeds were sown in plastic pots with gravel as a substrate, moistened with filtered water and placed in a growth chamber (PITEC, Model BIOREF-38) at c. $26{ }^{\circ} \mathrm{C}$ with a $14: 10 \mathrm{~h}$ (day/night) photoperiod. Germination was recorded daily for 30 days, or until no germinating seeds were observed for more than 7 days. The criterion used to consider a seed germinated was radicle emergence. To assess germination, one seed was sown per pot $(n=100$ pots per treatment). Seeds for the control treatment were obtained from ripe fruits. To test for differences in germination among treatments, the Kaplan-Meier survival function was estimated and then compared using a log-rank test with Bonferroni adjustment [23]. Analyses were performed in R software [24].

\section{Recruitment of E. acida in the field}

To assess juvenile recruitment, we recorded the number of young (less than $30 \mathrm{~cm}$ height), and adult individuals of $E$. acida in three patches of similar size inside the Reserve (Patch 1: 0.80 ha, Patch 2: 0.68 ha, Patch 3: $0.65 \mathrm{ha}$ ) and outside the Reserve (Patch 1: 0.61 ha, Patch 2: 0.75 ha, Patch 3: 0.75 ha). The areas were approximately $1 \mathrm{~km}$ apart and have similar characteristics of exposure, slope, vegetation composition and structure. Young individuals of E. acida were intensively searched on bare soil and under the bushes. A $X^{2}$ test was performed to evaluate differences in the stage structure between areas.

\section{Findings}

\section{Frugivore species inside the Reserve}

Three types of footprints were identified on the footprinttraps, corresponding to two bird species, the Chilean tinamou Nothoprocta perdicaria ( $n=19$ footprint-traps) and the Chilean mockingbird Mimus thenca ( $n=15$ footprint-traps), and one rodent species, the rodent $O$. degus ( $n=11$ footprint-traps). Only $N$. perdicaria can be suggested as a potential bird fruit consumer as fruits were found with signs of having been pecked $(n=6)$, albeit not enough to swallow seeds. On the other hand, $M$. thenca only pecked the fruit once; therefore, the evidence of fruit intake is insufficient. Only O. degus ate the fruits completely, carried the fruits to their caves, leaving only fruit remnants at the end of the thread ( $n=8$ footprint-traps).

\section{Effect of gut passage on seed germination}

In the no-choice feeding experiments, all the tested $O$. degus individuals consumed the whole fruit. Only 15 seeds were recovered, corresponding to $0.011 \%$ of the total ingested seeds (considering a mean of 1930 seeds/fruit). Because this rodent species destroyed most of the seeds passing through their digestive tracts, it cannot be considered a legitimate disperser for E. acida (sensu [25]). Both goats and guanacos ate fruits of E. acida, and many whole seeds were found in their feces. Seeds defecated by goats had the highest germination of all treatments $(60 \%)$ but did not differ from the control $(52 \%)\left(X^{2}=1.0, P=0.98\right)$ (Fig. 4). Seeds from guanacos germinated to a much lower extent than those from goats $(13 \%)\left(X^{2}=50.2, P<0.001\right)$. Likewise, seeds defecated by $L$. guanicoe germinated significantly less than control seeds $\left(X^{2}=36.4, P<0.001\right)$.

\section{Eulychnia acida recruitment}

Regarding cactus recruitment, there was a lower proportion of young individuals inside than outside the Reserve 


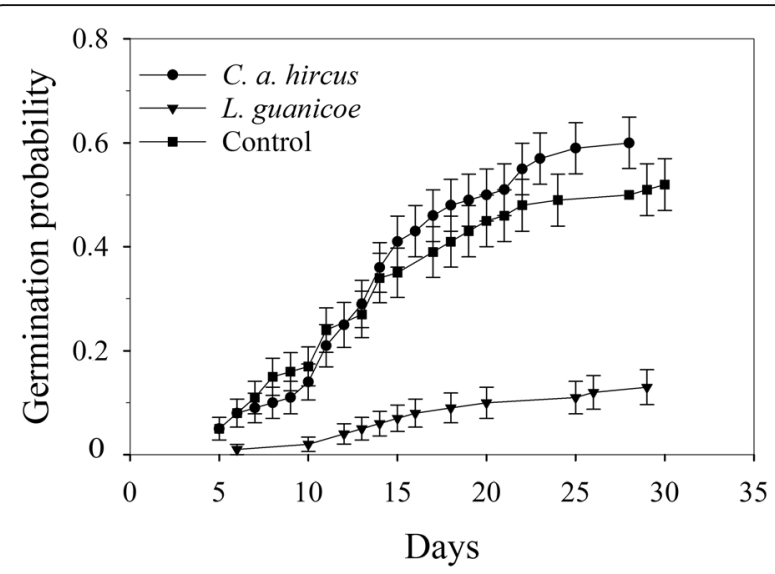

Fig. 4 Kaplan-Meier estimates of survivorship for germination of Eulychnia acida seeds after guanaco, goat, and control treatments

$\left(X^{2}=17.31, P<0.001\right.$, Fig. 5$)$. A total of 30 young and 186 adult individuals were recorded in 2.15 ha inside the Reserve, while outside the protected area a total of 104 young and 254 adult individuals were recorded in 2.11 ha. This result suggests that E. acida finds better conditions for dispersal and/or germination outside than inside the Reserve, which is likely related to the presence of goats outside.

\section{Discussion}

In this study, we examined the consumers of E. acida fruits in a protected area to determine the native species potentially involved in seed dispersal of this cactus species. We detected fruits with marks of having been pecked by two bird species, $N$. perdicaria and $M$. thenca. However, these birds did not eat enough of the fruit to ingest seeds, therefore they cannot be considered legitimate seed dispersers (sensu [25]). A previous study indicated that birds behave as seed dispersers of Trichocereus chiloensis (sin. Echinopsis chiloensis) a columnar cactus with ripe fruits that stay open on the cactus branch, exposing the sugared pulp to seed dispersers [26]. Unlike T. chiloensis, the fruits of E. acida are indehiscent and present an acidic pulp [27], which is not preferred by birds. Our evidence indicates that $O$. degus was the only mammal species consuming fruits of $E$. acida during the sampling time. However, almost all seeds ingested by $O$. degus were destroyed and only a few seeds could be recovered from their feces. This result was in line with a previous generalization that rodents behave as seed predators, as they kill most of the seeds through the gut passage [1]. In the light of these findings, we could conclude that the two-bird and one rodent species here examined cannot be considered legitimate seed dispersers (sensu [25]).

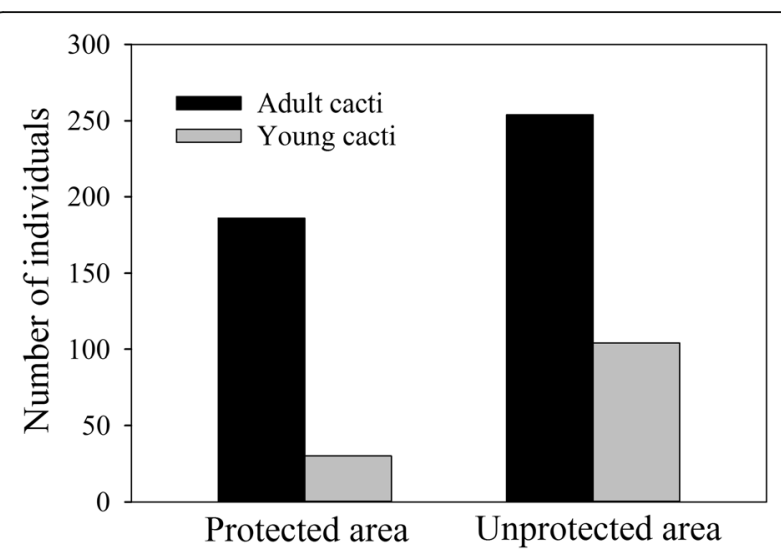

Fig. 5 Number of young and adult individuals of Eulychnia acida in two contrasting locations considering caprine livestock presence: protected and unprotected areas (inside and outside Las Chinchilllas National Reserve, respectively)

Regarding the seed dispersal syndrome concept, fruits often show characteristics associated with the type of seed disperser involved [8]. Our results suggest that fruits of $E$. acida are not suitable for most native fruit consumers present in the Reserve. Because our data indicate that $N$. perdicaria, $M$. thenca and O. degus are not legitimate seed dispersers, it is unlikely that fruit traits of E. acida do fit to the feeding preference of the native Chilean fauna at present. By contrast, goats eat fruits of E. acida, and seed gut passage does not affect germination negatively. As goats often defecate at random in the field [28], seeds may fall in potentially safe places by chance only. Therefore, we suggest that goats could potentially enhance population recruitment of $E$. acida, which may account, at least in part, for the higher density of young E. acida individuals observed outside than inside the Reserve.

Species of the cactus family often have very low recruitment rates by both vegetative and sexual reproduction in natural conditions $[29,30]$. In consequence, seed dispersers may play an important role as biotic agents that enhance the chance of germination and population recruitment [4]. Other studies have described goats as a potential seed disperser for cactus species in Mexico [16, 17], where goat husbandry is one of the main economic activities. This is also the case in north-central region of Chile $\left(27^{\circ} 22^{\prime} \mathrm{S}\right.$, $70^{\circ} 19^{\prime} \mathrm{W}$ to $33^{\circ} 3^{\prime} \mathrm{S}, 71^{\circ} 38^{\prime} \mathrm{W}$ ), where goat overstocking is one of the main activities contributing to desertification [31, 32]. Contrary to the general assumption that goat activity conveys mostly habitat loss and degradation, the present study suggests they may act as important dispersal agents of Eulychnia populations.

Several large herbivore mammals such as Gomphotheres became extinct in Pleistocene times [33], and probably some of them ate cactus fruits as they have been suggested to have generalist trophic habits [34]. 
One of the few large-sized mammal groups that survived megafauna Pleistocene extinctions was the genus Lama [35]. It is likely that Lama species were involved in the seed dispersal process of Eulychnia species until the arrival of the Spaniards, during the XVI century. Then, guanaco populations rapidly declined in number and its distribution is mostly circumscribed to high elevation areas in the Andes Range due to overhunting and occupation of pastures by cattle that consumed the native vegetation [36, 37]. Because the geographical distribution of $L$. guanicoe does not overlap with the Reserve location at present [38], we hypothesize that in the last centuries goats may have played a surrogate functional role for the seed dispersal process of $E$. acida. The experimental evidence that unlike L. guanicoe, goats do not decrease the seed germination of $E$. acida after gut passage, suggests that in the absence of native frugivore species introduced goats might play an important role in the seed dispersal process of the endemic cactus E. acida, extending Janzen and Martin's (1982) anachronism hypothesis to the Chilean Mediterranean ecosystem.

\section{Conclusions}

Our results indicate that fruits of E. acida are pecked by $N$. perdicaria and $M$. thenca, and eaten by the rodent $O$. degus. However, none of these species could be considered a legitimate seed disperser. Unlike $L$. guanicoe, the goat $C$. a. hircus, a species introduced by humans in semiarid Chilean ecosystems, consumed fruits of $E$. acida without decreasing seed germination. Indeed, our data indicate that variation in stage structure, a proxy of plant recruitment, between protected and unprotected areas may result from goat activity favoring cactus recruitment in areas where native dispersers are no longer present. Overall, the results of this study are compatible with Janzen and Martin's (1982) anachronism hypothesis for tropical ecosystems, extended to the Chilean Mediterranean ecosystem.

\section{Acknowledgements \\ We thank: A Bacigalupo, P Arroyo, P Cares, J Silva, R Garrido and N Peña for fieldwork assistance; G Rojo and A Sandoval for laboratory support; M Sallaberry for footprint identification; and J Cañas and J Abarca for authorization to use their photographs. RAC thanks the Laboratorio de Ecología de Comunidades, UNAM, Mexico. RAC and CSC thank the Chilean National Zoo for allowing feeding experiments with guanacos. CONAF allowed part of this research at Las Chinchillas National Reserve. \\ Funding \\ Financial support was provided by FONDECYT 1170367 and 1180850. RAC obtained a Research Residence Fellowship from the Departamento de Postgrado y Postítulo, Vicerrectoría de Asuntos Académicos, Universidad de Chile, and a CONICYT-Fellowship for Master's Studies. AVB and RM received funding support by CYTED P417RT0228.}

\section{Availability of data and materials}

The datasets used and/or analyzed during the current study are available from the corresponding author on reasonable request.

\section{Authors' contributions}

Experimental design: CBM, RM, RAC, CSC. Fieldwork: RAC and CSC. Performed the experiments: CSC and RAC. Data analysis: RAC, CSC, CBM, RM and AVB. Manuscript preparation: RAC, CSC, CBM, RM and AVB. All authors read and approved the final version of the manuscript.

Ethics approval and consent to participate

The captive conditions of $O$. degus were approved by the Ethics Committee of the Faculty of Medicine of University of Chile (CBA $\neq 0443 \mathrm{FMUCH})$.

Consent for publication

Not applicable.

\section{Competing interests}

The authors declare that they have no competing interests.

\section{Publisher's Note}

Springer Nature remains neutral with regard to jurisdictional claims in published maps and institutional affiliations.

\section{Author details}

'Departamento de Ciencias Ecológicas, Facultad de Ciencias, Universidad de Chile, Las Palmeras 3425, Nuñoa, Santiago, Chile. ${ }^{2}$ Instituto de Ecología, Universidad Nacional Autónoma de México, Apartado Postal 70-275, 04510 Coyoacán, Distrito Federal, Mexico.

Received: 27 March 2018 Accepted: 5 September 2018 Published online: 25 September 2018

\section{References}

1. Howe HF, Smallwood J. Ecology of seed dispersal. Annu Rev Ecol Syst. 1982; 13:201-28.

2. Willson MF, Traveset A. The ecology of seed dispersal. In: Fenner M, editor. Seeds: the ecology of regeneration in plant communities. London: CABl; 2000. p. 85-110.

3. Godínez-Álvarez H, Valiente-Banuet A, Rojas-Martínez A. The role of seed dispersers in the population dynamics of the columnar cactus Neobuxbaumia tetetzo. Ecology. 2002;83:2617-29.

4. Herrera CM. Seed dispersal by vertebrates. In: Herrera CM, Pellmyr O, editors, Plant animal interactions: an evolutionary approach. Oxford: Wiley-Blackwell; 2002. p. 185-208.

5. Schupp EW. Quantity, quality and the effectiveness of seed dispersal by animals. Vegetatio. 1993;107(108):15-29.

6. Traveset A, Robertson AW, Rodríguez-Pérez J. A review on the role of endozoochory in seed germination. In: Dennis AJ, Green RJ, Schupp EW, Westcott DA, editors. Seed dispersal: theory and its application in a changing world. London: CABl; 2007. p. 78-103.

7. Gautier-Hion A, Duplantier JM, Quris R, Feer F, Sourd C, Decoux JP, Dubost G, Emmons L, Erard C, Hecketsweiler P, Moungazi A, Roussilhon C, Tliiollay $J M$. Fruit characters as a basis of fruit choice and seed dispersal in a tropical forest vertebrate community. Oecologia. 1985;65:324-37.

8. Jordano P. Angiosperm fleshy fruits and seed dispersers: a comparative analysis of adaptation and constraints in plant-animal interactions. Am Nat. 1995;145:163-91.

9. Guimaraes PR Jr, Galetti M, Jordano P. Seed dispersal anachronisms: rethinking the fruits extinct megafauna ate. PLoS One. 2008;3:e1745

10. Janzen DH, Martin PS. Neotropical anachronisms: the fruits the Gomphotheres ate. Science. 1982;215:19-27.

11. Donatti C, Galetti M, Pizo M, Guimaraes PR Jr, Jordano P. Living in the land of ghosts: fruit traits and the importance of large mammals as seed dispersers in the Pantanal, Brazil. In: Dennis AJ, Green RJ, Schupp EW, Westcott DA, editors. Seed dispersal: theory and its application in a changing world. London: CABI; 2007. p. 104-23.

12. Cares RA, Muñoz PA, Medel R, Botto-Mahan C. Factors affecting cactus recruitment in semiarid Chile: a role for nurse effects? Flora. 2013;208:330-5.

13. Señoret F, Acosta JP. In: de Campo G, editor. Cactáceas endémicas de Chile. Concepción: CORMA; 2013.

14. Hoffmann AE, Walter HE. Cactáceas en la flora Silvestre de Chile. Santiago: Ediciones Fundación Claudio Gay; 2014.

15. Medel R. Assessment of parasite-mediated selection in a host-parasite system in plants. Ecology. 2000;81:1554-64. 
16. Baraza E, Valiente-Banuet A. Seed dispersal by domestic goats in a semiarid thornscrub of Mexico. J Arid Environ. 2008;72:1973-6.

17. Baraza E, Fernández-Osores $\mathrm{S}$. The role of domestic goats in the conservation of four endangered species of cactus: between dispersers and predators. Appl Veg Sci. 2013;16:561-70.

18. Carrasco GO. Mamíferos Fósiles de Chile. Talcahuano: Editorial Ocho Libros; 2009.

19. Raedeke KJ, Simonetti J. Food habits of Lama guanicoe in the Atacama Desert of northern Chile. J Mammal. 1988;69:198-201.

20. di Castri F, Hajek ER. Bioclimatología de Chile. Santiago: Ediciones de la Universidad Católica de Chile; 1976.

21. Medel R, Vergara E, Silva A, Kalin-Arroyo M. Effects of vector behavior and host resistance on mistletoe aggregation. Ecology. 2004;85:120-6.

22. Medel R, Botto-Mahan C, Smith-Ramírez C, Méndez MA, Ossa CG, Caputo L, Gonzáles WL. Historia natural cuantitativa de una relación parásito-hospedero: e sistema Tristerix-cactáceas en Chile semiárido. Rev Chil Hist Nat. 2002:75:127-40.

23. Nair J, Sunkara A, Frobish D. How to analyse seed germination data using statistical time-to-event analysis: non-parametric and semi-parametric methods. Seed Sci Res. 2012;22:77-95.

24. Team RC. R: A language and environment for statistical computing (version 3.0. 2). Vienna: R Foundation for Statistical Computing; 2014.

25. Jordano P, Schupp EW. Seed disperser effectiveness: the quantity component and patterns of seed rain for Prunus mahaleb. Ecol Monogr. 2000;70:591-615.

26. Cares RA, Medel R, Botto-Mahan C. Frugivory in Echinopsis chiloensis (Caryophyllales: Cactaceae). Rev Chil Hist Nat. 2013;86:489-91.

27. Salvatierra A, León-Lobos P, Benavides A, Larraín P, Olguín G, Córdova AM Martínez L, Martínez E, Maldonado A. Valorización de recurso genético nativo: Potencial productivo y económico-comercial de Eulychnia acida Phil., cactácea de la IV región, Chile. México, UNAM: Boletín de la Sociedad Latinoamericana y del Caribe de Cactáceas y otras Suculentas; 2006. p. 15.

28. Haenlein GFW, Caccese R, Sammelwitz PH. Behaviour goat extension handbook. Newark: University of Delware; 1992. p. 1-7.

29. Janzen DH. Chihuahuan desert nopaleras: defaunated big mammal vegetation. Annu Rev Ecol Evol Syst. 1986;17:595-636.

30. Salvatierra A. Recomendaciones para la propagación del copao o rumpa. Boletín \#42 Instituto de Investigaciones Agropecuarias. La Serena: Centro Regional de Investigadores Intihuasi; 2014

31. Fuentes ER, Hajek ER. Patterns of landscape modification in relation to agricultural practice in Central Chile. Environ Conserv. 1979;6:265-71.

32. Olivares AE. Pastizales y producción animal en zonas áridas de Chile. Science et changements planétaires/Sécheresse. 2006;17:257-64.

33. Sánchez B, Prado JL, Alberdi MT. Feeding ecology, dispersal and extinction of south American Pleistocene Gomphotheres (Gomphoteriidae, Proboscidea). Paleobiology. 2004;30:146-61.

34. González-Guarda E, Petermann-Pichincura A, Tornero C, Domingo L, Agustí J, Pino M, Abarzúa AM, Capriles JM, Villavicencio NA, Labarca R, Tolorza V, Sevilla P, Rivals F. Multiproxy evidence for leaf-browsing and closed habitats in extinct proboscideans (Mammalia, Proboscidea) from Central Chile. PNAS. 2018;115:9258-63.

35. Wheeler JC. South American camelids: past, present and future. J Camelid Sci. 2012;5:1-24.

36. Grimberg-Pardo MP. Plan Nacional de Conservación del Guanaco (Lama guanicoe) en Chile 2010-2015, Macrozona Norte y Centro. Chile: CONAF; 2010.

37. Tala C. Lama guanicoe. Ficha resumen de especie. Ministerio de medio ambiente. http://www.mma.gob.cl/clasificacionespecies/index.htm. Accessed 26 July 2018

38. Iriarte A. Mamíferos de Chile. Barcelona: Linx Edicions; 2008.

Ready to submit your research? Choose BMC and benefit from:

- fast, convenient online submission

- thorough peer review by experienced researchers in your field

- rapid publication on acceptance

- support for research data, including large and complex data types

- gold Open Access which fosters wider collaboration and increased citations

- maximum visibility for your research: over $100 \mathrm{M}$ website views per year

At $\mathrm{BMC}$, research is always in progress.

Learn more biomedcentral.com/submissions 